\title{
Composite "graphene nanoplatelets - fluorine-containing polyamide": synthesis, properties and quantum-chemical simulation of electroconductivity
}

\author{
A.D.Kachkovsky ${ }^{1}$, E.L.Pavlenko ${ }^{2}$, E.V.Sheludko ${ }^{1}$, N.P.Kulish ${ }^{2}$, \\ O.P.Dmitrenko ${ }^{2}$, V.A.Sendyuk ${ }^{2}$, P.S.Smertenko ${ }^{3}$, \\ V.V.Kremenitsky ${ }^{4}$, O.P.Tarasyuk ${ }^{1}$, S.P.Rogalsky ${ }^{1}$ \\ ${ }^{1}$ V.Kukhar Institute of Bioorganic Chemistry and Petrochemistry, \\ National Academy of Sciences of Ukraine, \\ 50 Kharkovskoe schosse, 02160 Kyiv, Ukraine \\ ${ }^{2}$ T.Shevchenko Kyiv National University, Faculty of Physics, \\ 64/13 Volodimirska Str., 03022 Kyiv, Ukraine \\ ${ }^{3}$ V.Lashkaryov Institute of Semiconductor Physics, National Academy of \\ Sciences of Ukraine, 41 Nauki Ave., 03028 Kyiv, Ukraine \\ ${ }^{4}$ Technical Center, National Academy of Sciences of Ukraine, \\ 13 Pokrovskaya Str., 04070 Kyiv, Ukraine
}

Received September 5, 2018

\begin{abstract}
Considered in the article is the basic possibility of increasing of electric conductivity of thermostable fluorine-containing aromatic polyamide by its doping with graphene platelets. The raised concentration of a conducting graphene phase (78 wt. \%) in the top layer $(\sim 50 \mu \mathrm{m})$ of the film composite is established. The microstructure of cross-section of the film and topography of its surface are studied by SEM and AFM. Corresponding volt-ampere characteristics are resulted. Carried out here are quantum-chemical calculations of model system "a polyamide fragment + graphene strip": localization of boundary and close molecular orbitals in the composite and also distribution of spin density of the composite in electric field. Conductivity of the composite is explained within the framework of stacking interaction between $\pi$-systems of the polymer and graphene.

Keywords: graphene platelets, polyamide, microstructure, stacking interaction, current-voltage characteristics, spin density, boundary orbital.

Рассмотрена принципиальная возможность повышения электропроводимости термостойкого фторсодержащего ароматического полиамида путём его допирования пластинками графена. Установлена повышенная концентрация (78 масс.\%) проводящей фазы графена в верхнем слое ( 50 мкм) плёночного композита. Используя СЭМ и АСМ, изучена микроструктура поперечного сечения плёнки и топография его поверхности. Приведены соответствующие вольт-амперные характеристики. Проведены квантово-химические расчёты модельной системы "фрагмент полиамида + графеновая полоска": локализация граничных и близких молекулярных орбиталей в композите, распределение спиновой плотности композита в әлектрическом поле. Проводимость композита обсуждается в рамках стекинг-взаимодействия между $\pi$-системами полимера и графена.
\end{abstract}


Композит "нанопластинки графену - фторований поліамід": синтез, властивості та квантово-хімічне моделювання електропровідності. О.Д.Качковський, О.Л.Павлен ко, Є.В.Шелудько, М.П.Куліш, О.П.Длитренко, В.А.Сендюк, П.С.Слертенко, В.В.Креле ницький, О.П.Тарасюк, С.П.Рогальський.

Розглянуто принципову можливість підвищення електропровідності термостійкого фторованого ароматичного поліаміду шляхом його допування смужками графену. Встановлено підвищену концентрацію провідної фази (78 мас.\%) графену у верхньому шарі ( 50 мкм) плівкового композиту. Використовуючи CEM і ACM, вивчено мікроструктуру поперечного перерізу плівки і топографію його поверхні. Наведено відповідні вольтамперні характеристики. Проведено квантово-хімічні розрахунки модельної системи "фрагмент поліаміду + графенова смужка": локалізація граничних та близьких молекулярних орбіталей у композиті, розподіл щільності спину композиту в електричному полі. Провідність композиту пояснюється у рамках стекінг-взаємодії між $\pi$-системами полімеру і графену.

\section{Introduction}

Current-conducting materials on a polymeric base are of considerable interest for use in many practical applications, in particular, in electrical engineering, electronics and other areas as heaters, antistatic coatings, resistors etc. $[1,2]$. To work out effective current-conducting materials, heat-resistant heterochain polymers: polyimides, aromatic polyamides, polyethermaleimides etc. are applied as polymeric matrixes [35]. The development of functional materials with nanofillers is especially promising since the last have the properties different from these of compacted samples. In such nanomaterials the role of dimensional effects is especially considerable, as with reduction of the size of structural elements the interface role considerably increases and dimensional effects can bear quantum character [6]. Now intensive researches of graphene-quasi-two-dimensional (2D) material with unique properties that have predetermined its application in various areas of technics [7-10] are carried out.

The effective mass of carriers in graphene equals to zero that promotes the high mobility reaching $10^{5}-10^{6} \mathrm{~cm}^{2} / \mathrm{V} \cdot \mathrm{s}$ as well as ballistic character of conductivity at which carriers don't collide with the atoms located in points of a crystal lattice [7, 8]. These properties of graphene can be used for electrophysical properties of composites to modify. The use of graphene as nanofiller for composite, including, polymeric materials is of special interest. Doping of polymeric materials with graphene results in rising not only in electroconductivity but also appearing of new properties [11-14].

It should be noted that the influence of graphene as conducting filler on the properties of fluorinated heterochain polymers is practically not studied.
Therefore it was of interest to investigate the influence of graphene additives on electrophysical properties of the heat-resistant fluorinated aromatic polyamide which is dielectric in a non-doped condition.

The aim of the work is to study the possibility of increasing of electrophysical characteristics of heat-resistant aromatic fluorinecontaining polyamide by its doping with multilayered graphene (graphene nanoplateles) of various concentrations and also to carry out the simulation of conductivity of such composite by quantum-chemical method.

\section{Experimental}

To obtain composites, poly-layer graphene in the form of platelets (Industrial Grade Graphene Nanoplatelets, "Grafen Chemical Industries Co.", Ankara, Turkey) having the following characteristics [15] has been used (Table 1). The fluorinated polyamide PA-24 - poly(1-tetrafluorethoxy-2,4-phenyleneisophtalamide) - the analogue of "Phenylone" has been synthesized from fluorine-containing diamine and isophthalic acid dichloride. The structural formula of the polymer and its some properties [16] is resulted below.<smiles>CNc1cc(NC(=O)c2cccc(C(=O)O)c2)ccc1OC(F)(F)F</smiles>

Introduction of the fluorinated group lends big solubility in amide solvents to the polymer and raises ability to film forming. For unoriented films made of such polyamide tensile strength makes 68$78 \mathrm{MPa}$ which is possible to raise to $117-$ $127 \mathrm{MPa}$ by orientation stretching. The films sustain multiple bending in liquid nitrogen medium $\left(-196^{\circ} \mathrm{C}\right)$. 

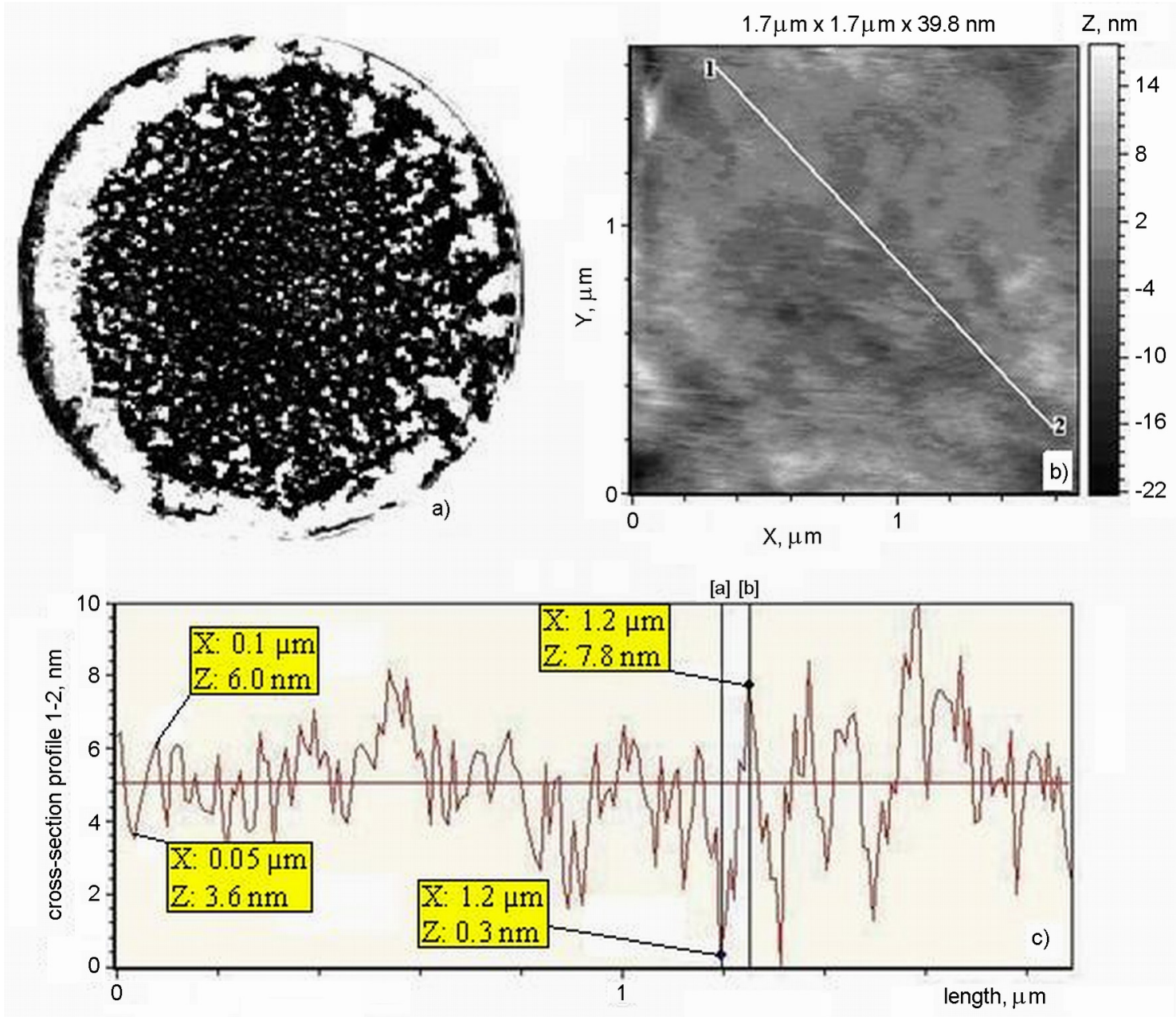

Fig. 1. Conducting graphene cluster in polyamide film (a): light area — polyamide film; dark one - graphene, topography (b) and cross-section profile 1-2 of composite top surface (c).

Table 1. Characteristics of graphene nanoplatelets

\begin{tabular}{|c|c||}
\hline Diameter (optional), $\mu \mathrm{m}$ & $5-44$ \\
\hline Oxygen content, \% & 1 \\
\hline Purity, $\%$ & $96-99$ \\
\hline Surface area, $\mathrm{m}^{2} / \mathrm{g}$ & $13-15$ \\
\hline Thickness, $\mathrm{nm}$ & $50-100$ \\
\hline
\end{tabular}

Table 2. Properties of the fluorinated polyamide PA-24

\begin{tabular}{|c|c||}
\hline $\begin{array}{c}\text { Temperature of destruction } \\
\text { beginning, }{ }^{\circ} \mathrm{C}\end{array}$ & 390 \\
\hline Density, $\mathrm{g} / \mathrm{cm}^{3}$ & 1.484 \\
\hline Tensile strength, $\mathrm{MPa}$ & $117-127$ \\
\hline Electrical resistivity, $\rho_{v}, \Omega \cdot \mathrm{cm}$ & $2.7 \cdot 10^{14}$ \\
\hline $\begin{array}{c}\text { Dielectric loss angle tangent } \\
\left(10^{3} \mathrm{~Hz}\right)\end{array}$ & 0.0086 \\
\hline
\end{tabular}

The process of a composite obtaining consists in pre-dispersing of the polymer solution in dimethylformamide with graphene sample within ultrasound (UZDN-2T disperser, Research-and-Production Enterprise "Akadempribor", Sumy, Ukraine, oscillation frequency $-22 \mathrm{kHz}$ ), film formation at $80^{\circ} \mathrm{C}$ on the glass form during $3 \mathrm{~h}$ followed by heat fixing (the film ends are fixed in clips) at $150^{\circ} \mathrm{C}$ to constant weight of the sample. The thickness of a film made 140-150 $\mu \mathrm{m}$.

Volt-ampere diagrams (VAD) have been defined at the specialized bench (the automated tester 14TKS-100, JSC "Testing Technology Center - Scientific and Production Association of Applied Mechanics", Zheleznogorsk, Russia). The values of voltage were raised step by step in $150 \mathrm{~ms}$ for each step and time of measurement $90 \mathrm{~ms}$.

The structure of a surface of the composite and its cross-section were studied with 


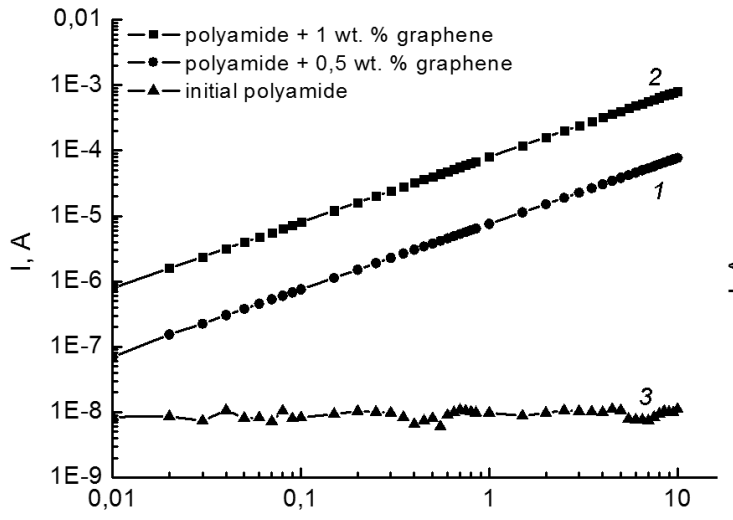

a)

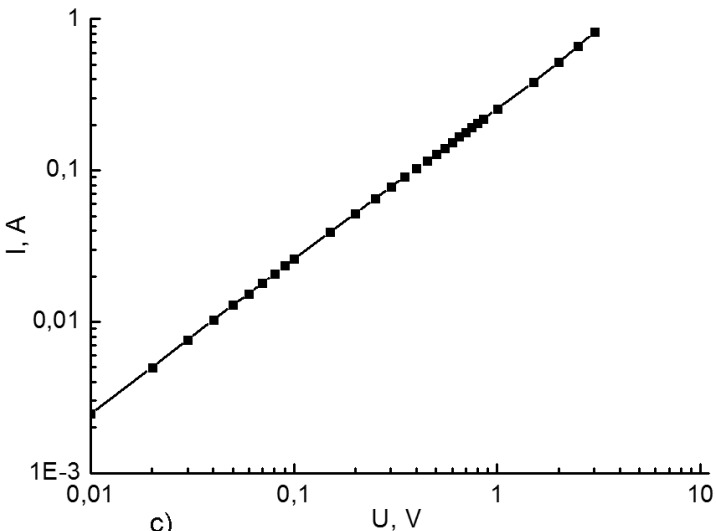

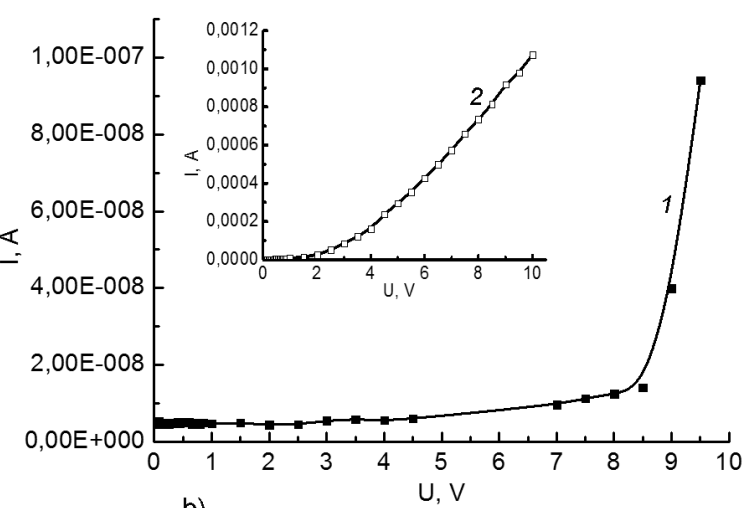

b)

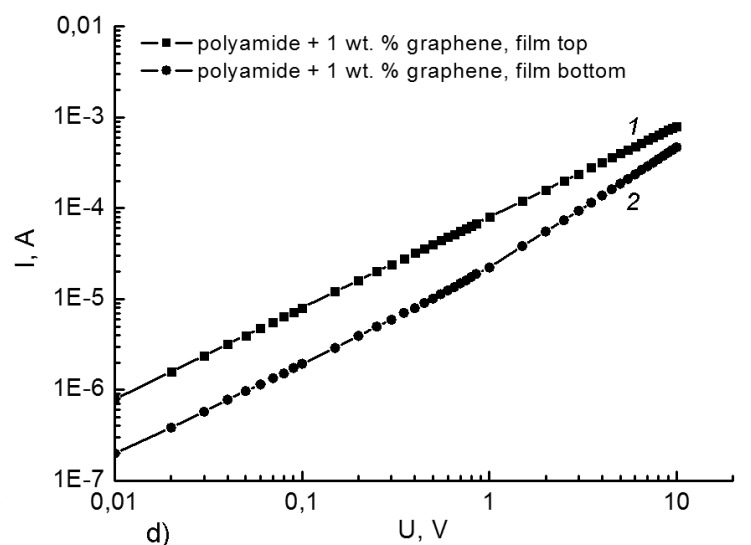

d)

Fig. 2. VADs of the composite: a - initial polyamide and the samples with content: $0.5 \%(1)$ and 1 wt. $\%$ (2); b - VADs of the samples with graphene in sandwich geometry: $1-0.5$ wt. $\% ; 2-$ 1 wt. $\%$; c - VAD of tableted sample with graphene content of 43.5 wt. $\%$; d - VADs of the samples from the top side of a surface (1) and from a substrate (2).

scanning electron microscope JEOL JSM6490(LV) supplied with EDS local microanalyzer. The surface morphology was investigated with atomic force microscope (AFM) NT-206 (Company with double liability "Microtestmachines", Gomel, Belarus) in a static mode.

\section{Results and discussion}

The image of graphene conducting cluster in the polyamide film at graphene concentration of 1 wt. $\%$ is presented in Fig. 1a.

Visually external surface of a film with the additive of $0,5 \mathrm{wt} . \%$ graphene is flat, bright, without ledges and hollows. The topography of the top part of the composite obtained with AFM in a static mode is presented in Fig. 1b. The surface roughness makes $R_{a}=2.7 \mathrm{~nm}$. The scatter of heights in the line of cross-section 1-2 makes 2.4$7.5 \mathrm{~nm}$. The surface roughness of the composite from a substrate is much more pronounced and makes $R_{a}=24.1-26.4 \mathrm{~nm}$.
Shown in Fig. 2a are VADs of the initial film and the samples with 0.5 and $1.0 \mathrm{wt} . \%$ of graphene. The initial sample of polyamide is dielectric. Introduction of 0.5 wt. $\%$ of graphene promotes increase in conductivity of polyamide tenfold. The rise of graphene content to 1 wt. $\%$ increases conductivity by 100 as compared with non-modified sample. VADs of the film composites taken in gap geometry are linear dependences in logarithmical coordinates. At the gap geometry, unlike sandwich-geometry, the film is located between two contacts forming among themselves a gap. At that the width of a gap is not less than in 10 times smaller than the length of contact strips.

Resulted in Fig. 2b are VADs of the samples with the content of graphene $0.5 \%$ (curve 1) and 1 wt.\% (curve 2) taken in sandwich geometry. In VADs it is possible to distinguish two values $(\sim 9 \mathrm{~V}$ at curve 1 , and $2 \mathrm{~V}$ at curve 2) of voltage whose further increase promotes sharp growth of composites conductivity. Thus, at larger graphene concentration 


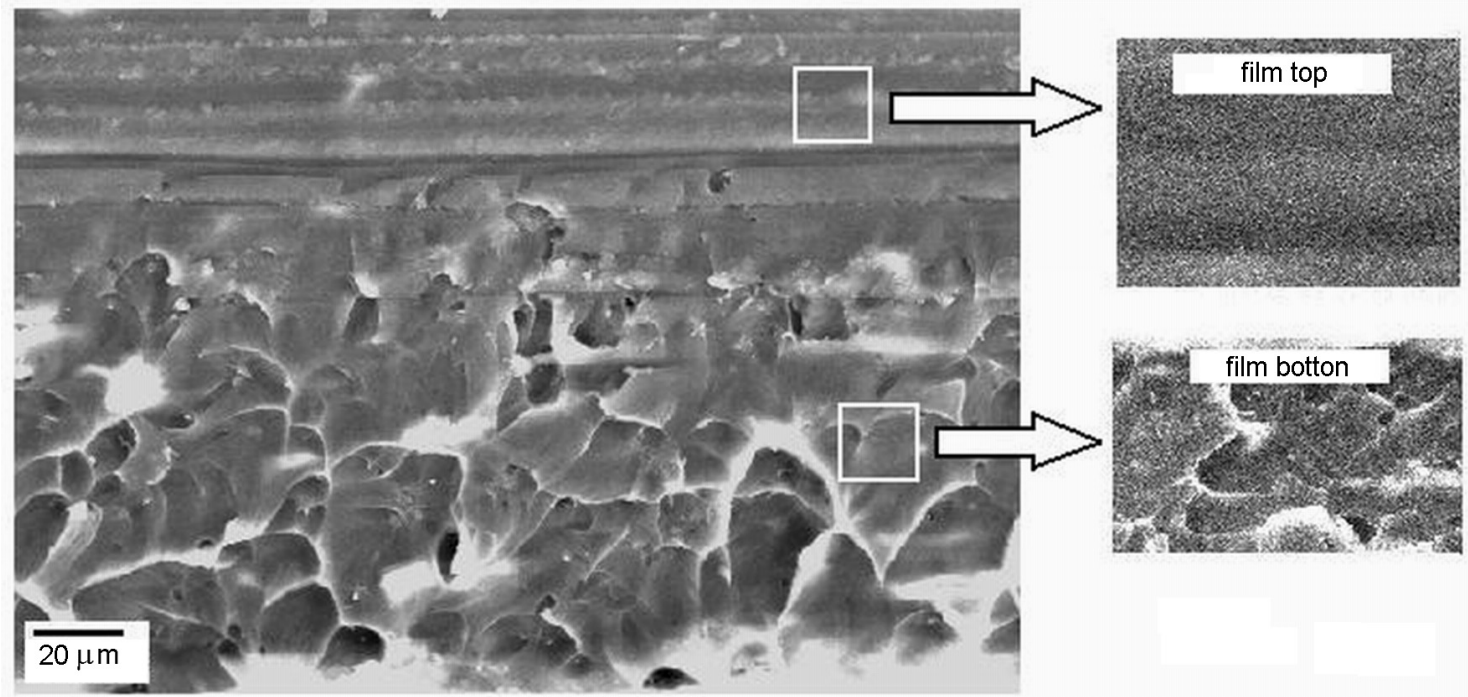

Fig. 3. The microstructure of cross section of composite film.

a smaller voltage for activation of carriers and conductivity increase is required. Resulted in Fig. 2c is VAD of the sample of the composite in the form of a tablet with the content of graphene 43.5 wt. $\%$. At such ratio of polyamide/graphene, conductivity practically raises by $10^{6}$ and polyamide from dielectric turns into conducting material having electrical resistivity $2.67 \Omega \cdot \mathrm{cm}$.

It should be noted the following feature of conductivity of the composites obtained. The conductivity of the film from the top surface side has appeared to be higher (in 4 times) than from a substrate (Fig. 2d).

This fact can indicate that the content of current-conducting graphene is higher at the top side of the composite that promotes the formation of conducting cluster. On the other hand, the introduction of graphene particles results in nanostructuring of the conducting layer (a thickness $\sim 50 \mu \mathrm{m}$ ) in such a way that compact packing of graphene platelets with a smaller dielectric layer between conducting phase is formed. In the layer with smaller electroconductivity $(\sim 100 \mu \mathrm{m})$ the polymeric "honeycomb" structure with smaller inclusions of a conducting phase is clearly visible. The microanalysis has shown that in the surface layer with larger conductivity the content of carbon makes about $78 \%$ (wt.) whereas in the layer from a substrate side - 7172 wt. $\%$. The image of cross-section of the composite film in secondary electrons is resulted in Fig. 3.

To interpret experimental data obtained and to work out the assumption of electro- conductivity mechanism, quantum-chemical calculations of a monomer link, a fragment of the polyamide consisting of two monomer links and also model graphene strip have been carried out. The calculations of equilibrium geometry of cooperating objects (the fragments of polyamide and graphene strip) have been conducted by ab initio method DFT/6-31(d,p)/CAM-B3LYP (Gaussian 03 [19]) and simulation of the influence of electric field was realized within the limits of AM1 semi-empirical method.

As can be seen from the formula of an elementary polyamide link, its main part is the conjugate system consisting of two benzene rings which are positioned in meta-position in a chain and related with peptide bond -CO-NH-. At the same time $\pi$-electrons of carbonyl group $\mathrm{C}=\mathrm{O}$ and unshared pair of electrons of -NH- group can be conjugated with $\pi$-electrons of benzene rings and form the general conjugate system. In spite of the fact that amide groups have flat trans-structure excluding the rotation round $\mathrm{C}-\mathrm{N}$ bond, the flexibility of chains in polyamides of this structure is caused by the rotation around $\mathrm{N}-\mathrm{Ph}$ and $\mathrm{C}-\mathrm{Ph}$ bonds [20]. This case is the reason why uniform collective $\pi$-electronic system seems not to form and, consequently, the polyamide film is dielectric. At the introduction of graphene, the interaction of $\pi$-systems of polyamide fragments and graphene strips is possible. $\pi$-Electronic systems are known to be able approaching for a distance of $3.4 \AA$, as for example, in aggregates of polymethine dyes [21] and effectively cooperate by the stack mechanism. For effective 
interaction between polymer and graphene strips it is necessary for graphene to overlap at least two monomer fragments of polyamide polymer.

Presented in Fig. $4 \mathrm{a}$ is the model of such interaction including 2 monomer links and minimal graphene strip consisting of 9 benzene rings of linear acene chain.

For simplicity, it is assumed that for the maximal stack interaction 2-monomer fragment will take on a flat structure. Naturally that graphene energy gap is significantly smaller than in polymer; in the limit it is equal to zero. The calculations of the model proposed show that energy levels of the gap in modeling polymer ( 2 monomer links) and modeling graphene (a linear chain of 9 benzene rings) mix up, however it can be seen from Fig. 4b that boundary orbitals (highest occupied molecular orbital - HOMO and lowest unoccupied molecular orbital - LUMO) are localized in graphene component and only HOMO-3 and LUMO+2 take part in delocalization of $\pi$-electrons. The estimation of a polyamide fragment MO-energy shows that the width of an energy gap makes $6.0 \mathrm{eV}$. In a complex "graphene fragment + polyamide link" the width of an energy gap considerably decreases and makes $4.4 \mathrm{eV}$. It can be explained by stack interaction of a polyamide link with graphene strip at which there is a filling of a polymer energy gap with graphene fragment states that leads to energy barrier reduction.

As a result, in pure polymer, conductivity is impossible because of considerable isolation of separate monomer fragments, while conductivity occurrence can be explained by formation of $\pi$-electronic "bridges" between monomer $\pi$-electronic sites of polyamide by means of stack interaction between $\pi$-systems of polymer and graphene. As a model, the distribution of spin density in the composite at the injection of one unpaired electron in conducting composite is calculated. As can be seen from experimental measurements, conductivity appears only at the applied field. The calculations also show that without the electric field application the spin density is localized only in modeling graphene strip. However, at the applied field with field strength of $E=0.001 \mathrm{~V} / \mathrm{m}$, both components of the composite take part in delocalization of unpaired injected electron. It is clear from the calculation the results of which are shown in Fig. 5a, b.

Hence, conductivity of polyamide doped by graphene can be assumed to arise from
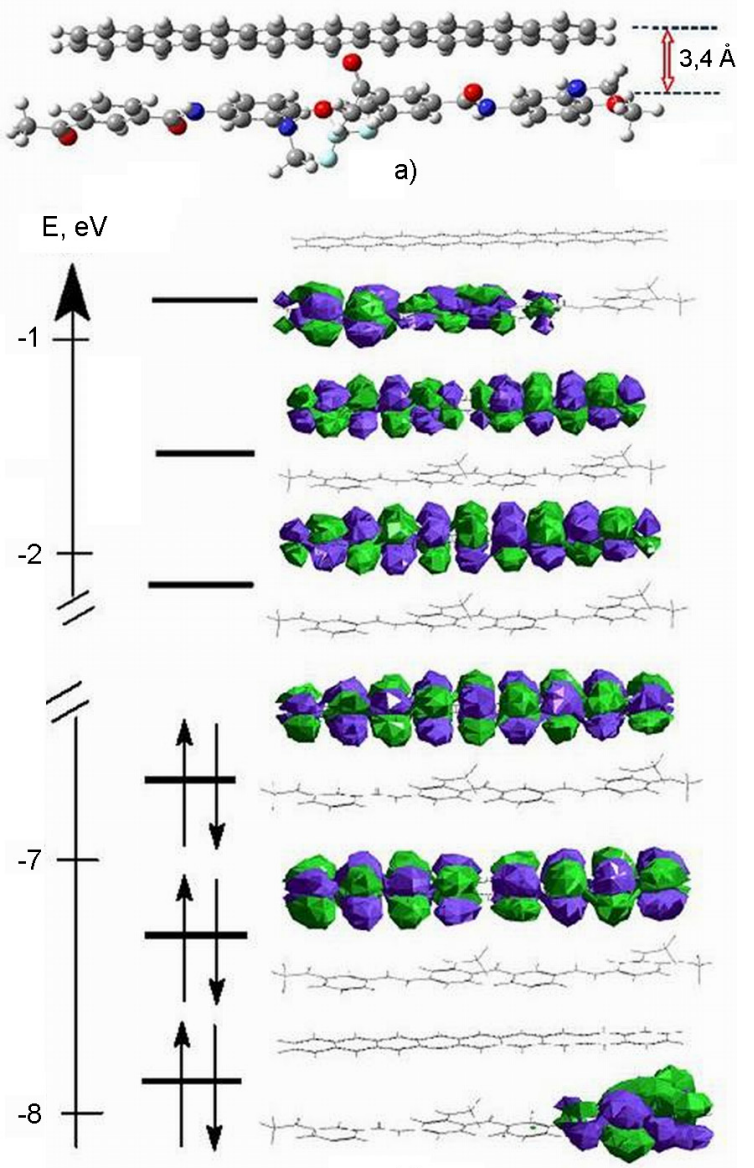

b)

Fig. 4, The model (a) of graphene strip (up) and polyamide of two elementary links (down) and localization of boundary and close molecular orbitals in the composite (b).

forming $\pi$-"bridges" between collective systems of $\pi$-electrons of both components interacting through the stack mechanism.

So, regulating the content of graphene at the formation of heat-resistant aromatic polyamide-based films it is possible to vary conductivity of such composite materials over a wide range.

\section{Conclusions}

So, for the first time in the work the composites on the base of aromatic fluorinecontaining polyamide and graphene nanoplatelets are obtained. The bilayered structure with the raised content of carbon in the top layer $(\sim 50 \mu \mathrm{m})$ is the feature of composites. When studying electroconductivity of the films in gap geometry, conductivity of the top layer at the content of $1 \%$ (wt.) graphene is established to be 100 more than from a substrate. The microstructure of cross-section of the film is studied, local microanalysis is carried out and the raised 


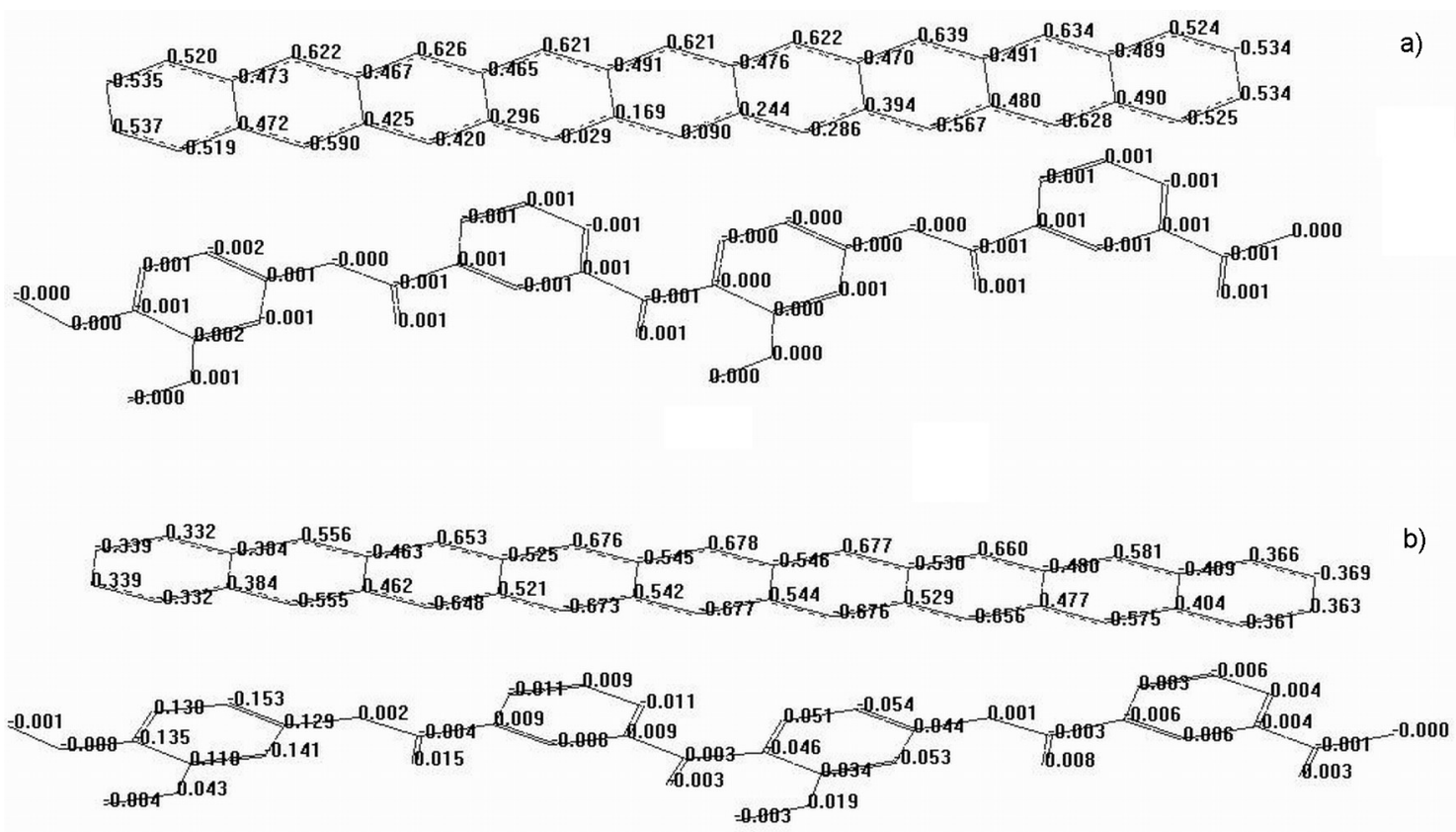

Fig. 5. The distribution of spin density of the composite in electric field: a $-E=0 \mathrm{~V} / \mathrm{m}$, $\mathrm{b}-E=0.001 \mathrm{~V} / \mathrm{m}$.

content of carbon in the top layer is confirmed. Quantum-chemical simulation of the system "polyamide fragment + graphene strip" is conducted; the energies of boundary and close MO as well as spin density distribution are calculated. In the framework of stack interactions the possible mechanism of electroconductivity in this modeling system is proposed.

The authors gratefully thank the company "Grafen Chemical Industries Co.", Ankara, Turkey for the samples of graphene nanoplatelets given for investigation.

\section{References}

1. Yu.A.Mikhailin, Polymernie Materiali, 9, 1 (2016).

2. A.A.Beznischchenko, N.A.Davidenko, V.N.Kokozey et al., Dopovidi of NAS Ukraine, 5, 136 (2007).

3. V.Ye.Gul', V.F.Blinov, M.G.Golubeva et al., Plasticheskie Massy, 9, 45 (1976).

4. U.Abdurahmanov, F.I.Boimuratov, G.I.Mukhamedov, Radiotekhnika i Elektronika, 55, 237 (2010).

5. T.I.Kolesnikova, L.I.Duhovny, I.Yu.Schelekhov et al., Application of Traditional and Development of New Film Materials: Digest of Scientific Articles, Frantsevich IPMS of NASU, Kyiv (1994), p.108.
6 R.A.Andrievsky, A.V.Khachoyan, Russian Khim.Zh., LIII, 4 (2009).

7. K.S.Novoselov, Usp.Phyz.Nauk, 181， 1299 (2011).

8. L.A.Chernozatonsky, P.B.Sorokin, A.A.Artyukh, Uspekhi Khimii, 83, 251 (2014).

9. D.Berman, A.Erdemir, A.Sumant, Mater. Today, 17, 31 (2014).

10. P.Blake, P.D.Brimicombe, R.R.Nair et al., Nano Lett., 8, 1704 (2008).

11. H.J.Salavagione, G.Martinez, G.Ellis, Physics and Application of Graphene - Experiments, ed. by Dr.Sergey Mikhailov, InTech (2011).

12. Fu.Xubing, Y.Chenguang, Y.Guisheng, RSC Advances, 76, 61688 (2015).

13. P.S.Krilov, A.S.Berestennikov, A.N.Aleschin et al., Fiz. Tverd. Tela, 57, 1639 (2015).

14. V.E.Muradyan, E.A.Sokolov, N.P.Piven' et al., Pisma v Zhurn. Teor. Fiz., 36, 106 (2010).

15. GRAFEN(r)-iGP/Industrial Graphene Nanoplatelets for General Purposes.- [Electronic resource]/Access mode: www.grafen.com.tr/products.php.

16. B.F.Malichenko, A.N.Tsipina, Vysokomol. Soed., B11, 361 (1979).

17. M.J.Frisch, G.W.Trucks, H.B Schlegel et al., GAUSSIAN03 Revision B.05, Pittsburgh, PA (2003).

18. V.N.Tsvetkov, Rigid Chain Polymer Molecules, Nauka, Leningrad (1986) [in Russian].

19. B.I.Schapiro, Uspehi Khimii, 75, 484 (2006). 